\title{
FUTURE WILDLIFE MANAGEMENT ON FOREST LANDS
}

\section{By BRUCE S. WRIGHT ${ }^{1}$}

I will break the practice of forestry into its major components and examine the implications of each on the field of wildlife management. These will be the points at which developments may be expected in the near future.

A long list of authors could be cited in support of the statement that the recreational use of forest lands is the fastest growing forest product in public demand to-day, but I will mention only two - Brockman (1959), and Brooks (1964). With the Age of Leisure virtually upon us, and the income from outdoor recreation soaring annually, it will soon be practical to undertake wildlife management practices that now seem economically impossible. The wildlife manager will soon be talking to the forest manager on a much more equal footing than he can to-day.

I know of no studies that have been done to put down in dollars and cents the cost of wildlife values of some of the detrimental forestry pratices that I am going to talk about, so that in this respect my discussion will lack support. However, this has always been the problem in trying to equate tangible and intangible values, and it must be accepted at the present state of our knowledge.

One of the most important aspects of pulpwood operations in eastern Canada is the spring drive. There are several aspects of stream driving that are detrimental to fish, wildlife, and recreation. The drive starts from the landing, the very formation of which may be very destructive to certain wildlife species. Landings are situated on the flood plains and flats along the feeder streams. All vegetation is removed by bulldozers to facilitate truck movements and to clear an area to place the piled pulpwood. These flats are the feeding grounds of woodcocks, among other wildlife, as they contain the best alluvial deposits in the area where earthworms are to be found. As the woodcock population from a mile or more on either side of the stream may come to this flat each night to feed, its conversion into a log landing which remains for many years as a bare strip long after the operation has moved elsewhere, affects a considerable area. The total of all landings so located may affect the feeding grounds of the woodcock population of the entire limits when it is remembered that some landings are six miles long holding 75,000 cords of pulpwood (Wright, 1962). This injurious practice could be ameliorated by requiring the operator to replant the landings at the end of his operation.

The practise of straightening streams and removing all obstacles to facilitate driving, which is done under the heading of "stream improvement," is now illegal in my home province of New Brunswick, but I am not sure that this is so all across the country. This practice is destructive to wildlife habitat,

${ }^{2}$ Northeastern Wildlife Station, University of New Brunswick, Fredericton, N.B. 
and to fish. Particularly on salmon rivers is it undesirable as it eliminates pools and spawning beds. When the water drops the logs grind over the gravel bars which act as a natural barking machine. This bark accumulates in the pools and presents a hazard to fish for many years. It takes up oxygen from the water as it decomposes and releases gases. This danger was well shown in Alberni harbour, B.C. a few years ago. A dredge working in the harbour dug into an old pile of sunken bark from a long-departed shingle mill. It released hydrogen sulphide in sufficient quantity to cause mass mortality among the fish in the harbour (Hourston and Herlinveaux, 1957). Gases from the decomposition of sunken bark are continually escaping into rivers used for driving.

The sweep operation following the drive is extremely destructive to all plant life along the shore as well as to the bank burrows of beaver, otter, mink, and muskrats. It is particularly destructive to nesting ducks and shorebirds as it takes place during the nesting period. This damage can be kept to a minimum by completing the drive as early as possible - preferably by June 1 .

When driving is practised on rivers heavily used for boating many conflicts arise. The drop-out logs strew the channel with deadheads, and as the free-running logs are at the mercy of winds and waterlevels, any marina or boat landing they pass may be closed in at any time. Protests in the past have been met with the answer that it is just not economically possible to boom the whole river. As the value of the other uses grows it will become economically necessary by public demand if this form of wood: transportation is to continue in some areas.

These are but a few of the detrimental effects of stream driving. I have discussed them more fully in another paper (Wright, 1962). The answer of course lies in moving the wood to the mill by land transport and abandoning driving. At present this would be uneconomic in some places, but as the value of the wildlife and recreational aspects increase this barrier will tend to disappear. In the past seasons in New Brunswick a big step forward has been made in the drive on the St. John River. It was completed by the end of May in several years which is a great improvement over previous years when the sweep crew often worked into late July. However, as driving must always be subject to wind and waterlevels which are beyond human control, any drive is a potential hazard to fish, wildlife, and recreation and its elimination in favor of land transport is desirable.

Another major area of conflict between forestry and wildlife is the practice of broad-scale spraying for forest insect control. In New Brunswick there has been only one year since 1952 that large areas of our forests have not been sprayed with DDT in June for spruce budworm control. This past summer about 1,800,000 acres were sprayed with DDT and an additional 160,000 acres of choice stream bottom covers were sprayed with phosphamidon. This was done in June during the nesting season of most birds. We have followed the effect of DDT spraying upon the breeding success of woodcocks over the last six years and we found an inverse relationship exists between breeding success and both the amount of DDT used and the area 
sprayed. We have also found DDT in such diverse food chains as those ending with bald eagles, black bears and ruffed grouse. In fact DDT has been found in every species so far analysed. The new biocide phosphamidon was used for the first time on a fairly large scale this year. It is purported to be less harmful to fish than DDT, but early indications are that it is much more harmful to birds. The Canadian Wildlife Service has started a study of its effects.

The pesticide problem is further complicated in migratory species. Our woodcocks winter in the southeastern states and Louisiana. This is the area where over 4,400,000 acres have been treated with heptachlor, dieldrin, and Mirex baits for fire ant eradication. New Brunswick woodcocks are now returning to the breeding grounds each spring heavily contaminated with heptachlor and DDT. The hen passes these two pesticides on to her eggs and the young are hatched contaminated with both. They acquire more of each locally during their first growing season, and by fall when they go south the joint contamination is widespread.

As $9,695,000$ pounds of DDT have been sprayed on 11,615,000 acres of New Brunswick between 1952 and 1963, and as the duration of DDT in the food chains of the region is as yet unknown, it seems probable that New Brunswick wildlife will be contaminated for a long time to come. This is apparently to be part of the price of pulpwood from this region, but you cannot expect any ecologist to like it.

We are under no delusions that woodcocks are the only species thus placed in double jeopardy. Other migratory species with similar feeding habits are almost certainly in the same sorry situation, but so far we have only looked at the woodcocks in sufficient numbers as they are an important game bird.

Some method is needed whereby tests for side effects on fish and wildlife can precede large-scale operational use. Last summer phosphamidon was used on 160,000 acres in New Brunswick, and the same season tests were undertaken for the first time to check its effects on birds. These effects were drastic, yet 160,000 acres were treated. One cannot help but wonder if a square mile would not have sufficed to tell us all we needed to know, but apparently there was never any question of awaiting the results, and the operation went forward as planned.

No biologist worth his salt is against pesticides per se. Pesticides are a tool and are apparently here to stay, but what does make a biologist want to bite off ten-penny nails is when he is asked to make experiments to test for side effects rather as an afterthought when the decision for the largescale use of the chemical has already been made. His attitude then becomes "What's the use? They are going to use it anyway no matter what $I$ find." This is where the thinking of foresters and wildlife biologists needs to be closer together, and it is here I would expect to see a great improvement in the near future.

How long it will take DDT and heptachlor to be bred out of New Brunswick woodcocks after the spraying is finally stopped is anybody's guess, 
but it will make an informative study. As forest spraying may be expected to continue for a long time to come, with (it is to be hoped) increasingly specific pesticides, there is need to develop antidotes for over-applications applied through carelessness or accident. An insecticide is required with low residual qualities and low vertebrate toxicity (Peterle and Giles, 1964). We do not yet have it.

The greatest hope for the total elimination of chemical control lies in the development of biological control. Studies in the field of sex attractants seem to offer promise. For example a chemical from virgin female sawflies is used to attract, capture, and remove males from the population. The exact chemical involved is not yet known, but research to isolate it in the pure form is underway (Coppel, Casida and Dauterman, 1960). Progress in this field will be vital to the whole forest insect problem.

Another important phase of forestry with wildlife implications is fire control. The barren-ground caribou winter in the northern coniferous forest where fruiticose lichens of the genera Cladonia and Cetaria make up their principal winter foods. These lichens grow in areas which in summer are dry and have a high fire hazard. They are only found in climax forest and do not appear in the early stages of forest succession, so that once burned the area is lost as winter range for a very long time in this slow growing region (Kelsall, 1960).

The barren-ground caribou are under heavy pressure from over-utilization and loss of winter range to fire. Improvements in fire fighting techniques which would extend the areas considered economically feasible to fight fire to include the principal winter range of the caribou, which is at present outside this area, would be a major breakthrough in caribou management.

On the other side of the coin, further experiments with controlled burning as a technique for managing deer and moose ranges is needed. The Indians used uncontrolled burns for this purpose before the white man came. Surely we ought to be able to improve on them a little. The present severe curtailment of fire as an ecological factor in Ontario is having drastic adverse effects upon the deer population. Here is a problem where the forester wants none at all of a vital ecological factor, and the wildlife biologist wants it badly at certain times and places which he will control. A getting together of minds on this problem is inevitable as the value of the wildlife resource increases.

A combination of modern methods of keeping a fire where you want it, fire-hazard research, browse studies, and big game management techniques already developed should produce a system of keeping forest land at its maximum big game production almost indefinitely. This could become one of the most useful of management tools when the demand for big game justifies giving it top priority in the land use plan.

Beaver management can also be closely tied in with fire control as the beaver population of the area is an important factor in supplying permanent water. The stage of forest succession is an important ingredient of beaver habitat so that silvicultural considerations will also be important in maintaining maximum beaver yields. 
As the economic gap between feasible silvicultural treatment of forest lands for wood products and for game narrows, I foresee many opportunities to aid wildlife by silviculture. On September 9, 1952, just twelve years ago, a milestone in this relationship was passed. On that day the Forest Supervisor of the Chequamegon National Forest in Wisconsin wrote the following memo to his forest rangers. It is still well worth quoting in part:-

"Deer yards to be considered in management plans have been located... Yards will be located there as deemed necessary and the following policy will apply.

"Within the deer yards ... and strips 10 chains wide surrounding them, management needs under the PR Project for deer browse production will take precedence over timber production needs. This does not mean that no timber sales will be made in those areas. Except for small conifer 'islands' which the Project Leader will designate to be left uncut for deer cover, timber sales may be made as in the rest of the area. We will cooperate with the Project Leader in making small sales in these areas which he deems desirable from the standpoint of deer management, to the extent practicable. Modifications of the forest slash disposal requirements will be permitted on such sales as recommended by the Project Leader.

"Other management measures planned for these areas will be described ... and submitted by the Project Leader in triplicate for approval by the District Ranger concerned and the Forest Supervisor prior to initiating the work. Such measures will include:

(a) Discing to stimulate reproduction in sparse stands.

(b) Thinning for the purpose of stimulating deer browse production. No conifers will be cut in such thinnings. No thinnings will be made in mature or near mature stands that have sales possibilities in the near future. Thinnings in young hardwood stands may be heavier than desirable from the silvicultural standpoint, but well-formed dominant and codominant trees of the following species in order of priority will be favored for leaving:

1. Yellow birch

2. Basswood

3. White oak

4. Sugar maple

5. Oak

6. Paper birch

7. Red maple

8. Elm

9. Black ash

(c) Cull trees (those with an estimated sound content of less than $331 / 3 \%$ of the total scale) may be cut to provide immediate browse, or girdled to create openings for browse production.

"After sufficient information has been gathered from present experimental management work, long range management plans for each permanent deer yard will be prepared ..." (Dahlberg and Guettinger, 1956).

Similar programs have now been initiated in Ontario. During the winter of 1962-1963 seven projects of this type were carried out in five important deer districts. In its first year of operation 610 acres of deer habitat were improved. Commercial logging in winter deer concentration areas resulted in improvement of deer habitat on approximately 4,100 acres in four important 
deer areas (Wright, 1964). In 1963, twelve habitat improvement projects were underway in the eastern deer range (south and east of Sault Ste. Marie and North Bay). These entailed strip and patch cutting and girdling. A total of 613 acres were so treated. Another project consisted of marking hemlocks to be left for deer shelter on 1,500 acres, and another consisted of a slash disposal programme following a 1962 cut.

Much more of this type of habitat improvement work can be justified as the value of the wildlife resource increases. There are many thousands of acres of moose and deer range in the Maritimes and elsewhere which could be improved in this way and this is entirely dependent upon the co-operation of the forester.

However, a word of warning on certain types of silvicultural improvements of timber stands. In the U.S.A. this has been done in some areas by either cleaning out all the old "wolf trees", including the den trees, in order to get younger stands of the same species or others; or by bulldozing and crushing down all hardwoods and replanting the area to pine or spruce. This is extremely hard on all forest wildlife, and is not an acceptable practise on any areas where these values are important. This has caused many disputes between foresters and wildlife biologists in the U.S.A., and is a pitfall we can afford to avoid in Canada. This type of stand improvement is being tested in New Brunswick now and 10,000 - 12,000 areas have already been treated in this manner in an effort to turn unprofitable hardwood ridges into pure stands of spruce. The results will bear close watching in terms of budworms and wildlife as well as stand improvement.

An increase in the use of private lands for public hunting in the U.S.A. has been brought about by co-operative agreements between the landowners and the state. These agreements provide that the state will take over responsibility for the management of the wildlife and the protection of property from vandalism and fire if the owner allows public hunting. A major difficulty in these agreements in the past has been the legal liability of the landowner for accidents occuring on his lands. This is in the process of being solved with new legislation to remove this liability. Similar developments can be expected along these lines in Canada.

These are all of the major points of contact between forestry and wildlife management that there is time to take up today. Forestry practises, or lack of them, affect wildlife from coast to coast, and north to the edge of the barrens. The power saw is heard today from the timbered islands in the bogs of Newfoundland so well beloved by caribou in flytime, to the rain forest of Admiralty Island, the home of the great brown bear. I have dwelt on the points of conflict between forestry and wildlife management because this paper is to discuss the future developments of this relationship and it is here that they may be expected. In closing, let me give an example of how forestry and wildlife management can be happy bedfellows.

This is the policy governing each in the National Forests of Virginia. Twenty-six years ago an agreement was signed between the U.S. Forest Service and the Virginia Commission of Game and Inland Fisheries that provided for a fee of $\$ 1.00$ to be paid by anyone wanting to hunt, trap, or 
fish on the National Forests. These funds were to be used to protect, restock, and provide habitat improvement for fish and wildlife.

In the 25th year of the agreement 100,000 licences were sold, and wildlife populations have been brought back from near extinction to record abundance (Virginia Commission of Game and Inland Fisheries, George Washington National Forest and Jefferson National Forest, 1963).

To sum up I would expect advances in wildlife management on forest lands in the near future to center around stream driving as compared with trucking; pesticides in the development of more specific toxins less harmful to vertebrates with low residual properties, and therapeutics for faulty applications; fire control extended to important wildlife areas not at present covered, and the development of controlled burning as a habitat management tool; silvicultural treatment of big game and fur bearer ranges applied on a much extended scale as wildlife values increase to justify it.

This in turn will call for more and better research in both wildlife and forestry, and an increase in technical personnel. The day of the mentality of Daniel Boone and Paul Bunyon are behind us. We are both in business today - and we intend to stay there.

\section{REFERENCES}

BROCKMAN, C. F. 1959. Recreational use of wild lands. McGraw Hill Book Co. Inc. New York, Toronto and London. 346 pp. Illus.

BROOKS, L. 1964. Demands of forest recreation on the forester and our forest resources. Forestry Chronicle 40 (1). March 111-115.

COPPELL, H. C., J. E. CASIDA and W. C. DAUTERMAN. 1960. Evidence for a potent sex attractant in the introduced pine sawfly, Diprion similis (Hymenoptera: Diprionidea). Ann. Ent. Soc. Amer. 53:510-512.

DAHLBERG, B. L. and RALPH C. GUETTINGER. 1956. The white-tailed deer in Wisconsin. Tech. Wildl. Bull. 14. Game Mgmt. Div. Wisc. Conservation Dept. Madison 1, Wisc. 278-279.

HOURSTON, A. S. and R. H. HERLINVEAUX. 1957. A "mass mortality" of fish in Alberni harbour, B.C. Fish. Res. Bd. Canada. Pacific Progress Report No. 109. 3-6.

KELSALL, J. F. 1960. Co-operative studies of the barren-ground caribou. Wildl. Mgmt. Bull. (1) 15. Northern Affairs and National Resources, Ottawa. 145 pp. Illus.

PETERLE, T. J. and R. H. GILES Jr. 1964. New tracer techniques for evaluating the effects of an insecticide on the ecolgoy of a forest fauna. R. F. Project 1207, Report 3. Ohio State Unir. Res. Foundation, Columbus 12, Ohio, to U.S. Atomic Energy Comm. Argonne, Ill. Jan. 435 pp.

Virginia Commission of Game and Inland Fisheries, George Washington National Forest and Jefferson National Forest. 1963. Co-operative wildlife management on Virginia National Forests. 24 pp. Illus. June.

WRIGHT, B. S. 1962. Effect of stream driving on fish, wildlife, and recreation. Woodlands Review Section, Pulp and Paper Magazine of Canada. November. 7 pp. Illus.

1964. Annual Report Standing Committee on Wildlife. Special Supplement to the Forestry Chronicle. Serial No. 168. March. 8-13. 